\title{
Bronchopulmonary dysplasia: Pathogenesis and treatment (Review)
}

\author{
ASFIA BANU PASHA, XIAO-QING CHEN and GUO-PING ZHOU \\ Department of Pediatrics, The First Affiliated Hospital, School of International Education, Nanjing Medical University, \\ Nanjing, Jiangsu 210029, P.R. China
}

Received March 2, 2018; Accepted July 6, 2018

DOI: $10.3892 /$ etm.2018.6780

\begin{abstract}
Bronchopulmonary dysplasia (BPD) is a form of chronic lung disease of infancy, which mostly affects premature infants with significant morbidity and mortality. Premature infants who require to be treated for conditions including respiratory distress syndrome have a higher risk of developing BPD. In spite of the improvement in clinical methods, the incidence of BPD has not reduced. In the present review, the pathogenesis of $\mathrm{BPD}$ is described along with the treatments available at present and the role of nursing in the management of BPD. Emerging preventive therapies for BPD are also discussed, including the use of recombinant human superoxide dismutase, which has been proven effective in reducing respiratory injury and its long-term effects.
\end{abstract}

\section{Contents}

1. Introduction

2. Pathogenesis

3. Treatment

4. Recent preventive therapy

5. Role of nursing in the management of BPD

6. Conclusions

\section{Introduction}

Preterm infants have immature lungs and for the development of lungs and correcting respiration, the infants are treated with surfactants, prenatal steroids and oxygen support, which may

Correspondence to: Dr Guo-Ping Zhou and Dr Xiao-Qing Chen, Department of Pediatrics, The First Affiliated Hospital, School of International Education, Nanjing Medical University, 140 Hanzhong Road, Nanjing, Jiangsu 210029, P.R. China

E-mail: guopzhou@126.com

E-mail: chenxq2002@foxmail.com

Key words: bronchopulmonary dysplasia, inflammation, preterm, hyperoxia be given through continuous positive airway pressure (CPAP) or mechanical ventilation (1-4). Apart from premature infants, full-term infants who are born with acute lung injury also require intensive ventilation support. This treatment, given for acute and chronic lung injury, has been identified to be one of the causes of the development of bronchopulmonary dysplasia (BPD) in infants. The term 'new BPD' has been assigned to this condition due to the disruption of distal lung growth $(5,6)$. In the past decade, the overall incidence of BPD has remained the same in spite of the improvement of clinical methods (1,7-9). BPD is characterized by the presence of persistent respiratory signs and symptoms, including tachypnoea, tachycardia, increased respiratory effort with chest retractions, nasal flaring and grunting, and frequent desaturations.

BPD was previously characterized by the classic progressive stages with prominent fibroproliferation $(5,6,10)$. This new form of the disease is encountered in preterm infants with a low inspired oxygen concentration during the early postnatal days or in those preterm infants who only required a small amount of or no ventilation support $(5,7,8)$. On histology, the lungs of infants with new BPD exhibited regions with more uniform and milder injury, as well as prominent impairment of alveolar and vascular growth (5).

\section{Pathogenesis}

While multiple causative factors are associated with BPD, the pre- and post-natal factors responsible for alveolar growth disruption are relatively well-defined. Apart from pre-term birth being the strongest cause, other causes, including pre-natal infections, mechanical ventilation, oxygen toxicity with decreased host anti-oxidant defense, patent ductus arteriosus and post-natal infection, also contribute to the pathogenesis of BPD. In addition, preeclampsia has recently been defined as a risk factor for the development of BPD (11-13). Abnormalities in the signaling of vascular endothelial growth factor (VEGF) have also been attributed to the pathogenesis of BPD (14-16). Impaired angiogenesis in preeclampsia has been reported as a basic pathological factor for the development of BPD (5,17-20). Preeclampsia has been associated with membrane-bound fms-like tyrosine kinase 1 (sFlt-1); this is a receptor for placental growth factor (PIGF) and VEGF. It is a pro-angiogenic protein with antagonistic activity to PIGF and VEGF. In preeclampsia, it is produced in high quantity by villous trophoblasts and 
hence, neutralizes PIGF and VEGF (5,16-20). Compared with healthy mothers, those with preeclampsia supply their foetuses with decreased levels of PIGF and VEGF and increased levels of sFlt-1 through their cord blood, which corresponds to the subsequent development of BPD (18). Alterations in VEGF signaling contribute to hyperoxia-induced vascular diseases in patients with BPD and retinopathy of prematurity (ROP) $(16,21-24)$. Certain studies have revealed that VEGF is decreased in tracheal fluid samples of premature neonates who were at risk of subsequent development of BPD, and lung VEGF and VEGF receptor (VEGFR)-1 expression were decreased in infants with BPD who died $(25,26)$. In animal studies, it has been identified that hyperoxia decreases the expression of alveolar VEGF $(27,28)$ and selective inhibition of VEGFR reduces lung vascular growth and alveolarization $(29,30)$. These results suggest that the communication between the endothelium and epithelium, particularly via VEGF signaling, is critical for the normal growth of lungs following birth, and disruption of VEGF signaling impairs the vascular growth of the lungs and alveolarization. An infection during the antenatal period has been identified as a contributing factor for injury to the baby's lungs, leading to BPD (31-34).

Pro-inflammatory cytokines including interleukin (IL)-1 $\beta$, IL-6 and IL-8, cytokine modifiers including p55, p75 and IL-1 receptor antagonist, C-reactive protein and tumor necrosis factor (TNF)- $\alpha$ are activated in inflammatory and infectious conditions, e.g. chorioamnionitis (35), and have been identified to be associated with the development of BPD in infants of affected mothers. These cytokines have been detected in the umbilical serum of infants born to mothers with severe chorioamnionitis (36). There is a correlation between elevated cytokine levels in chorioamnionitis and the subsequent development of BPD $(27,37,38)$. It has been demonstrated that these inflammatory changes may alter certain cell signaling pathways that are important in the morphogenesis of lung branching. For the development of lungs, including the promotion of airway extension and branching, fibroblast growth factor (FGF)-10 is among the key mesenchymal growth factors (39). Furthermore, nuclear factor (NF)- $\mathrm{kB}$ is known to promote the expression of numerous genes, including pro-inflammatory cytokines associated with the development of BPD. A variety of causes of cell stress, including infectious stimuli, inflammatory cytokines, damage and oxidants, are responsible for activating NF-кB $(27,40)$.

Apart from being increased in chorioamnionitis, cytokines also mediate acute lung injury $(41,42)$, aggravate ventilator-associated lung injury (43) and modulate the host defense (44), even in the absence of chorioamnionitis. Increased levels of cytokines have been observed in tracheal aspirates $(45,46)$ and serum of infants with respiratory distress syndrome $(47,48)$, which may predict the subsequent development of BPD. Specifically, increased levels of IL-1, IL-6, Il-8, IL 10 and interferon- $\gamma$, and low levels of IL-17 are indicators that may predict BPD $(27,28)$.

Changes in transforming growth factor (TGF)- $\beta 1$ signaling have been identified to be important in the pathogenesis of BPD. In a recent study, an association between TGF- $\beta 1$ levels in amniotic fluid, fatal lung injury and chorioamnionitis was demonstrated (49-51), hence indicating an association of pre-natal infection and inflammation with BPD (28).
Post-natal hyperoxia increases the production of cytotoxic oxygen free radicals, which, after exhausting the host's anti-oxidant defense mechanisms, cause lung injury (52-54). In pre-mature infants, the anti-oxidant enzyme system is deficient at birth and they have a low level of anti-oxidants, including vitamins $\mathrm{C}$ and $\mathrm{E}$, which decreases the expression of VEGF (29) and increases the vulnerability to oxygen toxicity, the expression of TGF- $\beta 1$ (55) as well as the levels of pro-inflammatory cytokines $(52,56)$. The necessity of mechanical ventilation after birth is correlated with the development of BPD. Mechanical ventilation increases the production of TNF- $\alpha$, IL-1 $\beta$, IL-6, IL-8 and IL-1 (57) and the expression of genes regulating angiogenesis in the lung is markedly altered (57). Anti-angiogenic genes whose production is increased in ventilated lungs include thrombospondin-1, collagen XVIII $\alpha-1$, tissue inhibitor of metalloproteinase-1, endoglin, TGF- $\alpha$ and monocyte chemoattractant protein-1. Pro-angiogenic genes whose expression is decreased include angiogenin and midkine, as well as VEGF-B, VEGFR-2 and the angiopoietin receptor TEK/Tie-2 $(22,52)$. An inverse association has been identified between the low partial pressure of carbon dioxide and the development of BPD (58). Hence, during early mechanical ventilation and even during resuscitation in the labor room, high tidal volumes should be avoided.

For pre-term infants (born before 28 weeks of gestation), who are at the verge of viability, one of the most essential treatments is mechanical ventilation $(58,59)$. Studies comparing volume-targeted ventilation with pressure-targeted ventilation indicated that the use of volume ventilation reduced the combined outcome of death or BPD, pneumothorax, number of days on the ventilator and hypocarbia (59-62). This was supported by the result of decreased levels of IL-6 and IL-8 in tracheal aspirates of infants treated with volume ventilation compared with those from infants who received pressure-targeted ventilation $(60,63)$. Furthermore studies suggested that the use of high-frequency oscillatory ventilation as a rescue treatment in infants with conventional mechanical ventilation decreased the incidence of BPD despite the treatment with surfactants $(60,64)$.

Patent ductus arteriosus (PDA) may also be associated with BPD. Long-term symptomatic PDA worsens pulmonary morbidity $(65,66)$. In a PDA with left to right shunt, the fluid efflux increases from the pulmonary vasculature to the lung parenchyma. The increased fluid in the lung interstitium increases the pulmonary microvascular filtration pressure and through an increase in the lung lymph flow, excess fluid is eliminated from the lung. This compensatory mechanism inhibits the accumulation of fluid in the lungs (67). When there is a persistent PDA, this compensatory mechanism becomes overwhelmed, which leads to the development of pulmonary oedema. This escalation more easily occurs in the presence of sepsis and RDS (7). In spite of an association between PDA and BPD, treatment of PDA, either by medical or surgical approaches, has not been proven to reduce the incidence of BPD. In fact, in one study, surgical ligation of the PDA increased the incidence of BPD (68).

The bone marrow and circulating lung endothelial cells are reduced by hyperoxia in the developing lungs (60-72). In preterm infants (born before 28 weeks of gestation), the circulating endothelial progenitor cells were identified to be important for the prevention of BPD (73-75). 


\section{Treatment}

BPD is thought to have a myriad of causative factors and treatment strategies applied to date have not been able to reduce the incidence of BPD. Therefore, strategies are required to focus mainly on preventing the development of BPD. Administration of steroids during the ante-natal period to a mother who is at high risk of preterm delivery reduces the incidence of respiratory distress syndrome, neonatal mortality and morbidity by $\sim 50 \%$, but does not reduce the incidence of BPD, even when combined with surfactant in the post-natal period. The ideal mode of ventilation remains to be determined, but the major strategy based on physiological studies is to maintain the tidal volume and inspired oxygen concentration as low as possible in order to avoid hypocarbia, volutrauma and oxygen toxicity.

Early use of nasal CPAP and avoidance of intubation and mechanical ventilation are alternative approaches to reduce BPD (76). It has been reported that early endotracheal intubation and mechanical ventilation in premature infants with a birth weight of 500-1,500 $\mathrm{g}$ is associated with an increased incidence of BPD (77). The preference of nasal CPAP with or without surfactant and the minimized use of mechanical ventilation were reported to reduce the incidence of BPD in infants with a high risk. Previous studies have demonstrated that CPAP may be used as an alternative to intubation and mechanical ventilation in preterm infants $(78,79)$. As pneumothorax is a common risk in infants subjected to CPAP, it was demonstrated that surfactants were efficacious in reducing air leak. Based on these studies, it may be concluded that such approaches (CPAP and surfactants) should be applied on populations which are likely to benefit from them, while they should be closely monitored for adverse events.

A meta-analysis concluded that supplementation with vitamin A to attain normal serum levels of retinol reduces the dependence on supplementary oxygen at 36 weeks of gestational age $(79,80)$, but does not have any effect on long-term outcomes. The vitamin A level should be carefully monitored. However, while supplementation proved beneficial in the short term, its beneficial effects on long-term neurological and pulmonary outcomes remain to be verified, which limits the use of this therapy.

Corticosteroid treatment, which is known to reduce inflammation in the lungs, which is present in infants at risk of developing BPD or who have already established BPD, is controversial. Corticosteroids have been consistently demonstrated to reduce inflammation in the lungs and inflammatory cells in tracheal samples of infants with BPD, and to improve the function of the lung and exchange of gases (80-82). A meta-analysis concluded that oxygen dependency at 28 days and 36 weeks of gestational age may be reduced if corticosteroids are given systemically within $96 \mathrm{~h} \mathrm{(83);} \mathrm{however,} \mathrm{there}$ are serious concerns regarding the side effects of corticosteroids on lung structure, physical and mental development, and risk of mortality (83-85). Scientific bodies including the American Academy of Paediatrics strongly discourage the routine and early use of corticosteroids in pre-mature newborns $(86,87)$. The conclusion on the adverse effects was drawn from studies in which administration of high doses of dexamethasone to the newborn was started within the first few days of life and continued for a long duration (88). The risk and benefit of the usage of steroids for short durations is still being questioned and studied. Therefore, it has been widely recommended to only use steroids after the first week of life at a low dose and for a short period of 5-7 days in infants with severe and persistent lung disease, who are dependent on a ventilator. As the use of dexamethasone is associated with a number of adverse effects, numerous studies have been performed on the use of hydrocortisone in the post-natal period for the prevention of BPD. As of now, the clear benefits of hydrocortisone have been demonstrated in all studies and it was concluded that the use of hydrocortisone is favoured. It has been proved that hydrocortisone reduces the mortality and increases the survival without BPD in infants who were exposed to chorioamnionitis in the prenatal period $(89,90)$. In all studies, no adverse effects of hydrocortisone have been demonstrated, regardless of whether it was used for a short or long term. The administration of hydrocortisone at a dose of $5 \mathrm{mg} / \mathrm{kg} /$ day then tapered over 3 weeks for infants who had developed BPD, has proved effective for reducing supplemental oxygen therapy and for weaning the infants from the ventilator with lesser short-term adverse effects and no long-term side effects (91). An increased incidence of gastrointestinal perforation has been noted in the use of hydrocortisone along with indomethacin (90). Therefore, the benefits of hydrocortisone require to be compared with this adverse effect in particular. It was identified that systemic administration of steroids produces more adverse effects, and in order to prevent them, steroid administration via the inhalation route has been attempted, but it failed to provide any obvious benefits. In a multicenter randomised trial, inhalation of betamethasone was associated with a decreased requirement for the systemic use of steroids (89-91). In other studies, it was demonstrated that the use of inhaled steroids for 1-4 weeks increased the rate of extubation, while not reducing the incidence of BPD (92-95).

One of the three large randomized control studies performed to date (87) concluded that the incidence of BPD was reduced by $50 \%$ in infants with a birth weight of $>1 \mathrm{~kg}$ and the incidence of brain injury in premature infants was decreased with the administration of corticosteroids by inhalation (87). A later study, however, suggested that early administration of a low dose of inhaled dexamethsaone does not prevent the subsequent development of BPD (88). Another study concluded that administering inhaled hydrocortisone and its tapered doses increased the survival rate without BPD and improved the short- and long-term function of the respiratory system (89).

Another available treatment for BPD is nitric oxide. Nitric oxide inhalation has been demonstrated to improve lung structure in a number of experiments (96). However, a clinical trial did not support the use of inhaled nitric oxide to prevent BPD in preterm infants (90). Another clinical trial (97) for the use of inhaled nitric oxide therapy for the prevention of BPD at high-risk preterm babies and the study of the effects of inhaled nitric oxide in infants with evolving BPD are still in progress.

Inhalation of nitric oxide is an important therapy for premature infants with pulmonary hypertension and pulmonary hypoplasia. It is the most effective and the safest 
treatment for pulmonary hypertension. In premature infants who have hypoxemia associated with pulmonary hypertension, inhalation of nitric oxide is the optimal treatment. It has been established that the use of inhaled nitric oxide at a dose of 5 ppm during the first week of life is safe. However, the use of inhaled nitric oxide at high doses in preterm infants with a birth weight of $<750 \mathrm{~g}$ may be associated with a high risk of intracranial hemorrhage (91).

\section{Recent preventive therapy}

An upcoming therapy for the prevention of BPD development is the supplementation of human recombinant anti-oxidant enzymes $(92,98)$. Certain studies performed on premature babies concluded that severe lung injury and inflammatory changes may be mitigated and the requirement for mechanical ventilation may be reduced with no associated adverse effects by prophylactic intratracheal administration of recombinant human $\mathrm{CuZn}$ superoxide dismutase (rhSOD). Prophylactic administration of intratracheal rhSOD to premature babies at birth with a birth weight ranging from 600 to $1,200 \mathrm{~g}$ and a high risk of developing BPD was associated with reduced respiratory episodes, including wheezing, asthma and respiratory infections, as concluded in a randomized placebo-controlled trial (98). Trials have suggested that rhSOD is able to prevent long-term lung injury due to oxygen exposure in high-risk pre-mature neonates $(99,100)$. Future studies will elucidate whether stem cell therapies provide a therapeutic benefit with sufficient safety (101).

\section{Role of nursing in the management of BPD}

Assessment of the child's respiratory and fluid status, skin color, breathing effort and abnormal sounds of breathing, chest retraction, capillary filling time, secretions, vital signs and edema every 1-4 h is important. Any deviation from the baseline is required to be reported.

Chest physiotherapy is required every $4 \mathrm{~h}$ as tolerated, suction should be performed 4 times per day as and when required and oxygen should be administered if necessary. Chest physiotherapy and suctioning help to remove mucus from the airways and lungs. The condition of the skin surface should be monitored if required. Bronchodilators should be administered to increase the airflow to the alveoli and diuretics should be added to reduce the risk of fluid retention and pulmonary edema, thereby improving the respiratory function.

Fluid intake and output should be carefully monitored in order to maintain adequate hydration, along with regular assessment of electrolyte levels and an increased fluid intake, if no contraindications exist. Close monitoring is important, as infants with BPD are susceptible to lower respiratory tract infections, hypertension and respiratory failure. Daily measurement of body weight, without clothes and with the same scales, is required in order to determine weight changes.

The diet plan of the child should be established according to the advice of a dietician, who should be informed on whether the child requires a high-calorie diet. In addition, the infants should be fed over a long time interval after which the infants need to be held in an upright position in order to enable them to burp. Feeding through a nasogastric (NG) tube, whenever required, particularly at night, and checking the placement of the NG tube prior to feeding to avoid aspiration are important care-taking steps in the management of BPD.

Regular care of the child with regard to bathing, clearing the airways and maintaining the skin is important along with informing parents about the details of the treatment and care of the baby with follow-up instructions.

\section{Conclusions}

BPD has continued to be a major complication of preterm birth since its first description 50 years ago. BPD is mainly characterized by various abnormalities in the development of the lungs. New therapies for the prevention and treatment of BPD are emerging and may result in an improvement of pre-mature infants in the long term. One of them is the use of rhSOD, which proved to be beneficial. Studies for assessing advanced therapies for the prevention and treatment of BPD and its long-term sequelae are yet to be performed/completed. The objective of our review was to correlate the pathogenesis of BPD and the treatment aspects to facilitate the development and application of improved and advanced therapies in order to not only treat the condition but also to prevent it. However, not all of the mechanisms leading to lung injury are completely understood. BPD is still one of the most vexing challenges in prematurity. Stem cell therapy may the most promising and fascinating method in the future.

\section{Acknowledgements}

Not applicable.

\section{Funding}

The present study was supported by the Six peak talent pro2016, China (grant no. 2016-WSN-090), National Natural Scientific fund of China (81741052) and the Priority Academic Program Development of Jiangsu Higher Education Institutions.

\section{Availability of data and materials}

Not applicable.

\section{Authors' contributions}

$\mathrm{AB}$ prepared the entire manuscript and read the literature on BPD. XC designed the present study. GZ drafted the manuscript and approved it for publication. The final version of the manuscript has been read and approved by all authors, and each author believes that the manuscript represents honest work.

\section{Ethical approval and consent to participate}

Not applicable.

\section{Patient consent for publication}

Not applicable. 


\section{Competing interests}

The authors declare that they have no competing interests.

\section{References}

1. Khetan R, Hurley M,Spencer S and Bhatt JM: Bronchopulmonary dysplasia within and beyond the neonatal unit. Adv Neonatal Care 16: 17-25; quiz E1-E2, 2016.

2. Northway WH Jr, Rosan RC and Porter DY: Pulmonary disease following respiratory therapy of hyaline membrane disease. Bronchopulmonary dysplasia. N Engl J Med 276: 357-368, 1967.

3. Bland RD: Neonatal Chronic Lung Disease in the Post-Surfactant Era. Biol Neonate 88: 181-191, 2005.

4. Jobe AH and Bancalari E: Bronchopulmonary dysplasia. Am J Respir Crit Care Med 163: 1723-1729, 2001.

5. Shahzad T, Radajewski S, Chao CM, Bellusci S and Ehrhardt H: Pathogenesis of bronchopulmonary dysplasia: When inflammation meets organ development. Mol Cell Pediatr 3: 23, 2016.

6. Jobe AJ: The new BPD: An arrest of lung development. Pediatr Res 46: 641-643, 1999.

7. Rojas MA, Gonzalez A, Bancalari E, Claure N, Poole C and Silva-Neto G: Changing trends in the epidemiology and pathogenesis of neonatal chronic lung disease. J Pediatr 126: 605-610, 1995.

8. Charafeddine L, D'Angio CT and Phelps DL: Aytypical chronic lung disease patterns in neonates. Pediatrics 103: 759-765, 1999.

9. Smith VC, Zupancic JA, McCormick MC, Croen LA, Greene J, Escobar GJ and Richardson DK: Trends in severe bronchopulmonary dysplasia rates between 1994 and 2002. J Pediatr 146 469-473, 2005

10. Hussain AN, Siddiqui NH and Stocker JT: Pathology of arrested acinar development in postsurfactant bronchopulmonary dysplasia. Hum Pathol 29: 710-717, 1998

11. Coalson JJ, Pathology of Bronchopulmonary Dysplasia, Semin Perinatol 30: 179-184, 2006.

12. Zhang H, Fang J, Su H and Chen M: Risk factors for bronehopulmonary dysplasiain neonates born at $\leq 1,500 \mathrm{~g}(1999-2009)$. Pediatr Int 53: 915-920, 2011

13. Hansen AR, Barnés CM, Folkman J and Chen M: Maternal preeclampsia predicts the development of bronchopulmonary dysplasia. J Pediatr 156: 532-536, 2010.

14. Jakkula M, Le Cras TD, Gebb S, Hirth KP, Tuder RM, Voelkel NF and Abman SH: Inhibition of angiogenesis decreases alveolarization in the developing rat lung. Am J Physiol Lung Cell Mol Physiol 279: L600-L607, 2000.

15. Tang JR, Markham NE, Lin YJ, McMurtry IF, Maxey A, Kinsella JP and Abman SH: Inhaled nitric oxide attenuates pulmonary hypertension and improves lung growth in infant rats after neonatal treatment with a VEGF receptor inhibitor. Am J Physiol Lung Cell Mol Physiol 287: L344-L351, 2004.

16. Yen TA, Yang HI, Hsieh WS, Chou HC, Chen CY, Tsou KI and Tsao PN; Taiwan Premature Infant Developmental Collaborative Study Group: Preeclampsia and the risk of bronchopulmonary dysplasia in VLBW infants: A population based study. PLoS One 8: e75168,2013.

17. McEvoy CT, Jain L, Schmidt B, Abman S, Bancalari E and Aschner JL: Bronchopulmonary dysplasia: NHLBI workshop on the primary prevention of chronic lung diseases. Ann Am Thorc Soc 11 (Suppl 3): S146-S153, 2014.

18. Karumanchi SA and Lindheimer MD: Advances in the understanding of eclampsia. Curr Hypertens Rep 10: 305-312, 2008.

19. Levine RJ, Lam C, Qian C, Yu KF, Maynard SE, Sachs BP, Sibai BM, Epstein FH, Romero R, Thadhani R, et al: Soluble endoglin and other circulating antiangiogenic factors in preeclampsia. N Engl J Med 355: 992-1005, 2006.

20. Foidart JM, Schaaps JP, Chantraine F, Munaut C and Lorquet S: Dysregulation of anti-angiogenic agents (sFlt-1, PLGF, and sEndoglin) in preeclampsia-a step forward but not the definitive answer. J Reprod Immunol 82: 106-111, 2009.

21. Tsao PN, Wei SC, Su YN, Chou HC, Chen CY and Hsieh WS Excess soluble fms-like tyrosine kinase 1 and low platelet counts in premature neonates of preeclamptic mothers. Pediatrics 116 : 468-472, 2005.

22. De Paepe ME, Greco D and Mao Q: Angiogenesis-related gene expression profiling in ventilated preterm human lungs. Exp Lung Res 36: 399-410, 2010.
23. Mailaparambil B, Krueger M, Heizmann U, Schlegel K, Heinze J and Heinzmann A: Genetic and epidemiological risk factors in the development of bronchopulmonary dysplasia. Dis Markers 29: 1-9, 2010

24. Lashkari K, Hirose T, Yazdany J, McMeel JW, Kazlauskas A and Rahimi N: Vascular endothelial growth factor and hepatocyte growth factor levels are differentially elevated in patients with advanced retinopathy of prematurity. Am J Pathol 156: 1337-1344, 2000

25. Bhatt AJ, Pryhuber GS, Huyck H, Watkins RH, Metlay LA and Maniscalco WM: Disrupted pulmonary vasculature and decreased vascular endothelial growth factor, Flt-1, and TIE-2 in human infants dying with bronchopulmonary dysplasia. Am J Respir Crit Care Med 164: 1971-1980, 2001.

26. Lassus P, Turanlahti M, Heikkilä P, Andersson LC, Nupponen I, Sarnesto A and Andersson S: Pulmonary vascular endothelial growth factor and Flt-1 in fetuses, in acute and chronic lung disease, and persistent pulmonary hypertension of the newborn. Am J Respir Crit Care Med 164: 1981-1987, 2001.

27. Ambalavanan N, Carlo WA, D'Angio CT, McDonald SA, Das A, Schendel D, Thorsen P and Higgins RD; Eunice Kennedy Shriver National Institute of Child Health and Human Development Neonatal Research Network: Cytokines associated with bronchopulmonary dysplasia or death in extremely low birth weight infants. Pediatrics 123: 1132-1141, 2009.

28. Maniscalco WM, Watkins RH, D'Angio CT and Ryan RM: Hyperoxic injury decreases alveolar epithelial cell expression of vascular endothelial growth factor (VEGF) in neonatal rabbit lung. Am J Respir Cell Mol Biol 16: 557-567, 1997.

29. Levy BD and Serhan CN: Resolution of acute inflammation in the lung. Annu Rev Physiol 76: 467-492, 2014.

30. Le Cras TD, Markham NE, Tuder RM, Voelkel NF and Abman SH: Treatment of newborn rats with a VEGF receptor inhibitor causes pulmonary hypertension and abnormal lung structure. Am J Physiol Lung Cell Mol Physiol 283: L555-L562, 2002.

31. Speer CP: Inflammation and bronchopulmonary dysplasia: A continuing story. Semin Fetal Neonatal Med 11: 354-362, 2006.

32. Watterberg KL, Demers LM, Scott SM and Murphy S: Chorioamnionitis and early lung inflammation in infants in whom bronchopulmonary dysplasia develops. Pediatrics 97: 210-215, 1996.

33. Kramer BW: Antenatal inflammation and lung injury: Prenatal origin of neonatal disease. J Perinatol 28 (Suppl 1): S21-S27, 2008.

34. Jonsson B, Rylander M and Faxelius G: Ureaplasma urealyticum, erythromycin and respiratory morbidity in high-risk preterm neonates. Acta Paediatrica 87: 1079-1084, 1998.

35. Døllner H, Vatten L, Halgunset J, Rahimipoor S and Austgulen R: Histologic chorioamnionitis and umbilical serum levels of pro-inflammatory cytokines and cytokine inhibitors. BJOG 109: 534-539, 2002.

36. Hartling L, Liang Y and Lacaze-Masmonteil T: Chorioamnionitis as a risk factor for bronchopulmonary dysplasia: A systematic review and meta-analysis. Arch Dis Child Fetal Neonatal Ed 97: F8-F17, 2012

37. Jobe AH: Blood cytokines and BPD. J Pediatr 154: A2, 2009.

38. Paananen R, Husa AK, Vuolteenaho R, Herva R, Kaukola T and Hallman M: Blood cytokines during the perinatal period in very preterm infants: Relationship of inflammatory response and bronchopulmonary dysplasia. J Pediatr 154: 39-43.e3, 2009.

39. Weaver M, Dunn NR and Hogan BL: Bmp4 and Fgf10 play opposing roles during lung bud morphogenesis. Development 127: 2695-2704, 2000.

40. Rothwarf DM and Karin M: The NF-kappa B activation pathway: A paradigm in information transfer from membrane to nucleus. Sci STKE 1999: RE1, 1999.

41. Benjamin JT, Carver BJ, Plosa EJ, Yamamoto Y, Miller JD, Liu JH, van der Meer R, Blackwell TS and Prince LS: NF-kappaB activation limits airway branching through inhibition of Sp1-mediated fibroblast growth factor-10 expression. J Immunol 185: 4896-4903, 2010.

42. Goodman RB, Pugin J, Lee JS and Matthay MA: Cytokine mediated inflammation in acute lung injury. Cytokine Growth Factor Rev 14: 523-535, 2003.

43. Belperio JA, Keane MP, Lynch JP III and Strieter RM: The role of cytokines during the pathogenesis of ventilator-associated and ventilator-induced lung injury. Semin Respir Crit Care Med 27: 350-364, 2006. 
44. Strieter RM, Belperio JA and Keane MP: Cytokines in innate host defense in the lung. J Clin Invest 109: 699-705, 2002.

45. Kotecha S, Wilson L, Wangoo A, Silverman M and Shaw RJ: Increase in interleukin (IL)-1 beta and IL-6 in bronchoalveolar lavage fluid obtained from infants with chronic lung disease of prematurity. Pediatr Res 40: 250-256, 1996.

46. Baier RJ, Majid A, Parupia H, Loggins J and Kruger TE: CC chemokine concentrations increase in respiratory distress syndrome and correlate with development of bronchopulmonary dysplasia. Pediatr Pulmonol 37: 137-148, 2004.

47. Vento G, Capoluongo E, Matassa PG, Concolino P, Vendettuoli V, Vaccarella C, Frezza S, Zuppi C, Romagnoli C and Ameglio F: Serum levels of seven cytokines in premature ventilated newborns: Correlations with old and new forms of bronchopulmonary dysplasia. Intensive Care Med 32: 723-730, 2006.

48. Viscardi RM, Muhumuza CK, Rodriguez A, Fairchild KD Sun CC, Gross GW, Campbell AB, Wilson PD, Hester L and Hasday JD: Inflammatory markers in intrauterine and fetal blood and cerebrospinal fluid compartments are associated with adverse pulmonary and neurologic outcomes in preterm infants. Pediatr Res 55: 1009-1017, 2004.

49. Kotecha S, Wangoo A, Silverman M and Shaw RJ: Increase in the concentration of transforming growth factor beta-1 in bronchoalveolar lavage fluid before development of chronic lung disease of prematurity. J Pediatr 128: 464-469, 1996.

50. Gauldie J, Galt T, Bonniaud P, Robbins C, Kelly M and Warburton D Transfer of the active form of transforming growth factor-betal gene to newborn rat lung induces changes consistent with bronchopulmonary dysplasia. Am J Pathol 163: 2575-2584, 2003.

51. Ichiba H, Saito $M$ and Yamano T: Amniotic fluid transforming growth factor-betal and the risk for the development of neonatal bronchopulmonary dysplasia. Neonatology 96: 156-161, 2009.

52. Buczynski BW, Maduekwe ET and O'Reilly MA: The role of hyperoxia in the pathogenesis of experimental BPD. Semin Perinatol 37: 69-78, 2013.

53. Bonikos DS, Benson KG and Northway WH Jr: Oxygen toxicity in the newborn. The effect of chronic continuous 100 percent oxygen exposure on the lung of newborn mice. Am J Pathol 85: 623-650, 1976

54. Crapo JD, Peters-Golden M, Marsh-Salin J and Shelburne JS: Pathologic changes in the lungs of oxygen-adapted rats: A morphometric analysis. Lab Invest 39: 640-653, 1978.

55. Dasgupta C, Sakurai R, Wang Y, Guo P, Ambalavanan N, Torday JS and Rehan VK: Hyperoxia-induced neonatal rat lung injury involves activation of TGF-\{beta\} and Wnt signaling and is protected by rosiglitazone. Am J Physiol Lung Cell Mol Physiol 296: L1031-L1041, 2009.

56. Warner BB, Stuart LA, Papes RA and Wispé JR: Functional and pathological effects of prolonged hyperoxia in neonatal mice. Am J Physiol 275: L110-L117, 1998

57. Tullus K, Noack GW, Burman LG, Nilsson R, Wretlind B and Brauner A: Elevated cytokine levels in tracheobronchial aspirate fluids from ventilator treated neonates with bronchopulmonary dysplasia. Eur J Pediatr 155: 112-116, 1996.

58. Kraybill EN, Runyan DK, Bose CL and Khan JH: Risk factors for chronic lung disease in infants with birth weights of 751 to 1000 grams. J Pediatr 115: 115-120, 1989.

59. Jobe AH, Hillman N, Polglase G, Kramer BW, Kallapur S and Pillow J: Injury and inflammation from resuscitation of the preterm infant. Neonatology 94: 190-196, 2008.

60. Wheeler K, Klingenberg C, McCallion N, Morley CJ and Davis PG: Volume-targeted versus pressure-limited ventilation in the neonate. Cochrane Database Syst. Rev 10: CD003666, 2010.

61. Björklund LJ, Ingimarsson J, Curstedt T, John J, Robertson B, Werner O and Vilstrup CT: Manual ventilation with a few large breaths at birth compromises the therapeutic effect of subsequent surfactant replacement in immature lungs. Pediatr Res 42 : 348-355, 1997.

62. Wheeler K, Klingenberg C, McCallion N, Morley CJ and Davis PG: Volume-targeted versus pressure-limited ventilation in the neonate. Cochrane Database Syst Rev 10: CD003666, 2010

63. Lista G, Colnaghi M, Castoldi F, Condò V, Reali R, Compagnoni G and Mosca F: Impact of targeted-volume ventilation on lung inflammatory response in preterm infants with respiratory distress syndrome (RDS). Pediatr Pulmonol 37: 510-514, 2004

64. Courtney SE, Durand DJ, Asselin JM, Hudak ML, Aschner JL and Shoemaker CT; Neonatal Ventilation Study Group High-frequency oscillatory ventilation versus conventional mechanical ventilation for very-low-birth-weight infants. N Engl J Med 347: 643-652, 2002.
65. Clyman RI: The role of patent ductus arteriosus and its treatments in the development of bronchopulmonary dysplasia. Semin Perinatol 37: 102-107, 2013.

66. Bancalari E, Claure N and Gonzalez A: Patent ductus arteriosus and respiratory outcome in premature infants. Biol Neonate 88: 192-201, 2005

67. Alpan G, Mauray F and Clyman RI: Effect of petent ductus arteriosus on water accumulation and protein permeability in the lungs of mechanically ventilated premature lambs. Pediatr Res 26: 570-575, 1989.

68. Chorne N, Leonard C, Piecuch R and Clyman RI: Patent ductus arteriosus and its treatment as risk factors for neonatal and neurodevelopmental morbidity. Pediatrics 119: 1165-1174, 2007.

69. Balasubramaniam V, Mervis CF, Maxey AM, Markham NE and Abman SH: Hyperoxia reduces bone marrow, circulating, and lung endothelial progenitor cells in the developing lung: Implications for the pathogenesis of bronchopulmonary dysplasia. Am J Physiol Lung Cell Mol Physiol 292: L1073-L1084, 2007.

70. van Haaften T, Byrne R, Bonnet S, Rochefort GY, Akabutu J, Bouchentouf M, Rey-Parra GJ, Galipeau J, Haromy A, Eaton F, et al: Airway delivery of mesenchymal stem cells prevents arrested alveolar growth in neonatal lung injury in rats. Am J Respir Crit Care Med 180: 1131-1142, 2009.

71. Javed MJ, Mead LE, Prater D, Bessler WK, Foster D, Case J, Goebel WS, Yoder MC, Haneline LS and Ingram DA: Endothelial colony forming cells and mesenchymal stem cells are enriched at different gestational ages in human umbilical cord blood. Pediatr Res 64: 68-73, 2008 .

72. van Hinsbergh VW and Rabelink TJ: FGFR1 and the Bloodline of the vasculature. Arterioscler Thromb Vasc Biol 25: 883-886, 2005.

73. Borghesi A, Massa M, Campanelli R, Bollani L, Tzialla C, Figar TA, Ferrari G, Bonetti E, Chiesa G, de Silvestri A, et al: Circulating endothelial progenitor cells in preterm infants with bronchopulmonary dysplasia. Am J Respir Crit Care Med 180: 540-546, 2009.

74. Pavlovic J, Papagaroufalis C, Xanthou M, Liu W, Fan R, Thomas NJ, Apostolidou I, Papathoma E, Megaloyianni E, DiAngelo $S$ and Floros J: Genetic variants of surfactant proteins $\mathrm{A}, \mathrm{B}, \mathrm{C}$ and D in bronchopulmonary dysplasia. Dis Markers 22: 277-291, 2006

75. Woodgate PG and Davies MW: Permissive hypercapnia for the prevention of morbidity and mortality in mechanically ventilated newborn infants. Cochrane Database Syst Rev: CD002061,2001.

76. Van Marter LJ, Allred EN, Pagano M, Sanocka U, Parad R, Moore M, Susser M, Paneth N and Leviton A: Do clinical markers of barotrauma and oxygen toxicity explain interhospital variation in rates of chronic lung disease? The Neonatology Committee for the Developmental Network. Pediatrics 105: 1194-1201, 2000.

77. Morley CJ, Davis PG, Doyle LW, Brion LP, Hascoet JM and Carlin JB; COIN Trial Investigators: Nasal CPAP or intubation at birth for very preterm infants. N Engl J Med 358: 700-708, 2008.

78. SUPPORT Study Group of the Eunice Kennedy Shriver NICHD Neonatal Research Network, Finer NN, Carlo WA, Walsh MC, Rich W, Gantz MG, Laptook AR, Yoder BA, Faix RG, Das A, et al: Early CPAP versus surfactant in extremely preterm infants. N Engl J Med 362: 1970-1979, 2010.

79. Darlow BA and Graham PJ: Vitamin A supplementation for preventing morbidity and mortality in very low birthweight infants. Cochrane Database Syst Rev: CD000501, 2002.

80. Jefferies AL: Postnatal corticosteroids to treat or prevent chronic lung disease in preterm infants. Paediatr Child Health 17: 573-574, 2012 (In English, French).

81. Yoder MC Jr, Chua R and Tepper R: Effect of dexamethasone on pulmonary inflammation and pulmonary function of ventilator-dependent infants with bronchopulmonary dysplasia. Am Rev Respir Dis 143: 1044-1048, 1991.

82. Halliday HL: Clinical trials of postnatal corticosteroids: Inhaled and systemic. Biol Neonate 76 (Suppl 1): S29-S40, 1999.

83. Tschanz SA, Damke BM and Burri PH: Influence of postnatally administered glucocorticoids on rat lung growth. Biol Neonate 68: 229-245, 1995.

84. Jobe AH: Postnatal corticosteroids for preterm infants-do what we say, not what we do. N Engl J Med 350: 1349-1351, 2004.

85. Garland JS, Alex CP, Pauly TH, Whitehead VL, Brand J, Winston JF, Samuels DP and McAuliffe TL: A three-day course of dexamethasone therapy to prevent chronic lung disease in ventilated neonates: A randomized trial. Pediatrics 104: 91-99, 1999. 
86. Committee on Fetus and Newborn: Postnatal corticosteroids to treat or prevent chronic lung disease in preterm infants. Pediatrics 109: 330-338, 2002.

87. Doyle LW, Halliday HL, Ehrenkranz RA, Davis PG and Sinclair JC: Impact of postnatal systemic corticosteroids on mortality and cerebral palsy in preterm infants: Effect modification by risk for chronic lung disease. Pediatrics 115: 655-661, 2005.

88. Onland W, Offringa M, De Jaegere AP and van Kaam AH: Finding the optimal postnatal dexamethasone regimen for preterm infants at risk of bronchopulmonary dysplasia: A systematic review of placebo controlled trials. Pediatrics 123: 367-377, 2009.

89. Baud O, Maury L, Lebail F, Ramful D, El Moussawi F, Nicaise C, Zupan-Simunek V, Coursol A, Beuchée A, Bolot P, et al: Effect of early low-dose hydrocortisone on survival without bronchopulmonary dysplasia in extremely preterm infants (PREMILOC): A double-blind, placebo-controlled, multicentre, randomised trial. Lancet 387: 1827-1836, 2016.

90. Mercier JC, Hummler H, Durrmeyer X, Sanchez-Luna M, Carnielli V, Field D, Greenough A, Van Overmeire B, Jonsson B, Hallman M, et al: Inhaled nitric oxide for prevention of bronchopulmonary dysplasia in premature babies (EUNO): A randomised controlled trial. Lancet 376: 346-354, 2010.

91. Watterberg KL, Gerdes JS, Cole CH, Aucott SW, Thilo EH, Mammel MC, Couser RJ, Garland JS, Rozycki HJ, Leach CL, et al: Prophylaxis of early adrenal insufficiency to prevent bronchopulmonary dysplasia: A multicenter trial. Pediatrics 114: 1649-1657, 2004.

92. Rademaker KJ, Uiterwaal CS, Groenendaal F, Venema MM, van Bel F, Beek FJ, van Haastert IC, Grobbee DE and de Vries LS: Neonatal hydrocortisone treatment: neurodevelopmental outcome and MRI at school age in preterm-born children. J Pediatr 150: 351-357, 2007.
93. Lister P, Iles R, Shaw B and Cucharme F: Inhaled steroids for neonatal chronic lung disease. Cochrane Database Syst Rev 4: CD002311, 2000.

94. Shah V, Ohlsson A, Halliday HL and Dunn M: Early administration of inhaled corticosteroids for preventing chronic lung disease in ventilated very low birth weight preterm neonates. Cochrane Database Syst Rev 16: CD001969, 2012.

95. Cole CH, Colton T, Shah BL, Abbasi S, MacKinnon BL, Demissie S and Frantz ID III: Early inhaled glucocorticoid therapy to prevent bronchopulmonary dysplasia. N Engl J Med 340: 1005-1010, 1999.

96. Lister P, Iles R, Shaw B and Ducharme F: Inhaled steroids for neonatal chronic lung disease. Cochrane Database Syst Rev: CD002311, 2000.

97. Cole FS, Alleyne C, Barks JD, Boyle RJ, Carroll JL, Dokken D, Edwards WH, Georgieff M, Gregory K, Johnston MV, et al: Inhaled nitric oxide therapy for premature infants. NIH Consens State Sci Statements 29: 27, 2010.

98. Poonyagariyagorn HK, Metzger S, Dikeman D, Mercado AL, Malinina A, Calvi C, McGrath-Morrow S and Neptune ER: Superoxide dismutase 3 dysregulation in a murine model of neonatal lung injury. Am J Respir Cell Mol Biol 51: 380-390, 2014.

99. Davis JM, Rosenfeld WN, Sanders RJ and Gonenne A: Prophylactic effects of recombinant human superoxide dismutase in neonatal lung injury. J Appl Physiol 74: 2234-2241, 1993.

100. Davis JM, Parad RB, Michele T, Allred E, Price A and Rosenfeld W; North American Recombinant Human CuZnSOD Study Group: Pulmonary outcome at 1 year corrected age in premature infants treated at birth with recombinant $\mathrm{CuZn}$ superoxide dismutase. Pediatrics 111: 469-476, 2003.

101. Vosdoganes P, Lim R, Moss TJM and Wallace EM: Cell therapy: A novel treatment approach for bronchopulmonary dysplasia. Pediatrics 130: 727-737, 2012. 